\title{
Big Data as the Universal Language for Barrett's Esophagus
}

\author{
Robert M. Genta
}

Published online: 13 September 2014

(C) Société Internationale de Chirurgie 2014

Eastern and Western gastroenterologists disagree on what endoscopic features define Barrett's esophagus: salmoncolored mucosa in the West [1] and distal palisading vascular arborizations in the East [2]. British and American pathologists (and many others who embrace either the British or the American viewpoint) disagree on what type of columnar mucosa must be seen in a biopsy specimen from the lower esophagus to seal a diagnosis of Barrett's mucosa [3, 4]. Eastern and Western pathologists-in spite of consensus meetings in Padua, Vienna, and other lovely venues - cannot decide what dysplasia is [5]. In addition to these geographic differences, locally codified and supported by venerable American, British, and Japanese professional associations [3, 6, 7], those supposedly united by common definitions are separated by an alarming degree of interobserver variability. In spite of Spechler's partiality to pink [1], other American endoscopists may have very different perceptions of the color of a salmon. Three goblet cells at the squamocolumnar junction may be sufficient for a pathologist to declare Barrett's esophagus and sentence the patient to a lifetime of surveillance and oncophobia, while a more prudent colleague would mention the very focal metaplasia without referring to the 'B' word. Since the 1980s, dysplasia in Barrett's mucosa has been the object of innumerable studies based on the highly deceptive, but inexplicably revered, $\kappa$ statistics, whose results can be cynically summarized as follows: there is good

R. M. Genta $(\bowtie)$

Miraca Life Sciences Research Institute, 6655 North MacArthur

Blvd, Irving, TX 75039, USA

e-mail: robert.genta@utsouthwestern.edu

\section{R. M. Genta}

Departments of Pathology and Medicine, University of Texas Southwestern Medical Center at Dallas, Dallas, TX, USA agreement on the absence of dysplasia and on the presence of high-grade dysplasia, but the categories 'indefinite' and 'low-grade' could just as well be decided by tossing dice [8, 9]. Yes, there is agreement on high-grade dysplasia, except that a Japanese and a German pathologist might call it cancer ... [5, 10].

In light of these radical differences, the question posed by Rugge et al. [11], "Are we speaking the same language?", rhetorically asked in the title of his insightful yet depressing article published in this issue of the World Journal of Surgery, comes as a gross understatement. In an unusually lucid and detached fashion, the authors present a systematic list of what prevents clinicopathologic consensus on Barrett's esophagus and its complications. The consequences of these different, and in some cases even conflicting, definitions and guidelines are easy to envision: a diagnostic and therapeutic study based on a certain set of criteria is largely irrelevant to a setting where different criteria apply. Or is it?

At a time when the concepts of tolerance and diversity are touted with almost religious fervor, the world seems to become ever more divided and less accepting of national boundaries, religious, linguistic, and ethnic differences, and there is little realistic hope that Rugge's tepid exhortation ("we need internationally accepted criteria") will be embraced soon. Other solutions are clearly needed, and some may be already available with help coming from two diverse sources: immigration studies and big data.

Several of the world's major countries were built on immigration or have opened their borders to people wishing to settle there. As a result, large segments of the population in North America, Oceania, and parts of Europe have their ancestral origin in other geographic areas. These countries, such as the USA and the UK, have well structured medical licensing, training, and specialty certification 
systems. Thus, one can assume that most, if not all, gastroenterologists licensed to practice in the USA and the UK have undergone training there, have passed their boards, are members of their national professional societies, and are familiar with the guidelines promulgated by them. A similar assumption can be made for pathologists. We can also assume that a gastroenterologist practicing in the USA will biopsy the esophagus according the guidelines of the American College of Gastroenterology, irrespective of the patient's national origin. While the US pathologist will diagnose Barrett's mucosa if there are goblet cells, and the UK pathologist will be content with columnar epithelium, in each country all patients will have had a relatively uniform endoscopic description of their distal esophagus and a diagnosis based on the locally accepted guidelines.

Reports have suggested that Barrett's esophagus is less common in East Asia than in the West [12]. To acquire some insights into these alleged differences, we used a large national pathology database of more than half a million patients with esophageal biopsies to investigate East Asian patients seen in the US medical system compared with non-Asian Americans. All esophageal biopsy specimens were evaluated by a single group of pathologists who used consistent criteria. We hypothesized that if the reported geographic differences were real, the prevalence in these populations would be similar to that found in the ancestral countries. On the other hand, if the differences were spurious, i.e., due to different clinical and histopathologic criteria used in those countries, there would be no significant variation amongst the ethnic groups. The prevalence of histologically confirmed Barrett's mucosa was $12.0 \%$ in non-Asian Americans and $6.1 \%$ in East Asians (with an odds ratio of 0.48 and $95 \%$ confidence interval 0.43-0.53). These numbers, comparable to those reported from previous Asian and American studies, suggest that when numbers are large enough, the influence of different criteria is obliterated [13].

The use of big data for clinical research is slowly gaining acceptance, in part based on the concept that database analysis can afford to sacrifice some accuracy in exchange for being able to include thousands or even millions of individual data points and paint a more reliable picture of reality [14]. In the case of Barrett's research, we may have to forego the unattainable dream of reaching for universal definitions of its anatomy, histology, and progressing steps. Instead, by studying available data from very large populations, we may get closer to a reality that will ultimately transcend the current definitional diatribes.

\section{References}

1. Spechler SJ (2013) Barrett's esophagus: the American perspective. Dig Dis 31:10-16

2. Takubo K, Vieth M, Aida J, Sawabe M, Kumagai Y, Hoshihara Y, Arai T (2009) Differences in the definitions used for esophageal and gastric diseases in different countries: endoscopic definition of the esophagogastric junction, the precursor of Barrett's adenocarcinoma, the definition of Barrett's esophagus, and histologic criteria for mucosal adenocarcinoma or high-grade dysplasia. Digestion 80:248-257

3. Fitzgerald RC, di Pietro M, Ragunath K, Ang Y, Kang JY, Watson P, Trudgill N, Patel P, Kaye PV, Sanders S, O'Donovan M, Bird-Lieberman E, Bhandari P, Jankowski JA, Attwood S, Parsons SL, Loft D, Lagergren J, Moayyedi P, Lyratzopoulos G, de Caestecker J, BritishSocietyof Gastroenterology (2014) British Society of Gastroenterology guidelines on the diagnosis and management of Barrett's oesophagus. Gut 63(1):7-42

4. Spechler SJ, Sharma P, Souza RF, Inadomi JM, Shaheen NJ (2011) American Gastroenterological Association medical position statement on the management of Barrett's esophagus. Gastroenterology 140:1084-1091

5. Genta RM (2000) Dysplasia east and west. Curr Gastroenterol Rep 2:465-470

6. Spechler SJ, Sharma P, Souza RF, Inadomi JM, Shaheen NJ (2011) American Gastroenterological Association technical review on the management of Barrett's esophagus. Gastroenterology 140:e18-e52

7. Kinjo T, Kusano C, Oda I, Gotoda T (2010) Prague C\&M and Japanese criteria: shades of Barrett's esophagus endoscopic diagnosis. J Gastroenterol 45:1039-1044

8. Reid BJ, Haggitt RC, Rubin CE, Roth G, Surawicz CM, Van Belle G, Lewin K, Weinstein WM, Antonioli DA, Goldman H et al (1988) Observer variation in the diagnosis of dysplasia in Barrett's esophagus. Hum Pathol 19(2):166-178

9. Montgomery E, Bronner MP, Goldblum JR, Greenson JK, Haber MM, Hart J, Lamps LW, Lauwers GY, Lazenby AJ, Lewin DN, Robert ME, Toledano AY, Shyr Y, Washington K (2001) Reproducibility of the diagnosis of dysplasia in Barrett esophagus: a reaffirmation. Hum Pathol 32:368-378

10. Schlemper RJ, Itabashi M, Kato Y, Lewin KJ, Riddell RH, Shimoda T, Sipponen P, Stolte M, Watanabe H, Takahashi H, Fujita $R$ (1997) Differences in diagnostic criteria for gastric carcinoma between Japanese and western pathologists. Lancet 349:17251729

11. Rugge M, Pizzi M, Castoro C (2014) Definition of Barrett's esophagus dysplasia: are we speaking the same language? World J Surg. doi:10.1007/s00268-014-2692-y

12. Chang CY, Cook MB, Lee YC, Lin JT, Ando T, Bhatia S, Chow WH, El-Omar EM, Goto H, Li YQ, McColl K, Reddy N, Rhee PL, Sharma P, Sung JJ, Ghoshal U, Wong JY, Wu JC, Zhang J, Ho KY (2011) Current status of Barrett's esophagus research in Asia. J Gastroenterol Hepatol 26:240-246

13. Genta RM, Spechler SJ (2014) Barrett's esophagus is not rare in Asian patients who have esophageal biopsies taken in the United States. Gastroenterology 146(5 Suppl 1):S-305

14. Genta RM, Sonnenberg A (2014) Big data in gastroenterology research. Nat Rev Gastroenterol Hepatol 11:386-390
Acknowledgments No funding or financial support was received for this work. The author has no potential or real conflicts of interest to disclose. 